TABLE VIII.-Children Rated by Teachers as Nervous at 13 and 15 Classified by Position in Family, Social Class, and Age When Having
Measles

\begin{tabular}{|c|c|c|c|c|}
\hline \multirow{2}{*}{$\begin{array}{c}\% \text { Rated Consistently as } \\
\text { Nervous }\end{array}$} & \multicolumn{4}{|c|}{ Age When Having Measles } \\
\hline & Before 2 & $2-5$ & $6-11$ & After 11 \\
\hline Middle-class $\quad \cdots\left\{\begin{array}{l}\text { Eldest } . . \\
\text { Other } \ldots\end{array}\right.$ & $\begin{array}{l}9 \cdot 6 \\
6 \cdot 4\end{array}$ & $\begin{array}{l}6 \cdot 6 \\
9 \cdot 3\end{array}$ & $\begin{array}{l}11 \cdot 1 \\
10 \cdot 3\end{array}$ & $\begin{array}{l}8 \cdot 8 \\
9 \cdot 5\end{array}$ \\
\hline Manual working class $\left\{\begin{array}{l}\text { Eldest } . . \\
\text { Other }{ }^{*} . .\end{array}\right.$ & $\begin{array}{r}18 \cdot 6 \\
7 \cdot 3\end{array}$ & $\begin{array}{r}10 \cdot 7 \\
9 \cdot 9\end{array}$ & $\begin{array}{l}16 \cdot 5 \\
11 \cdot 1\end{array}$ & $\begin{array}{l}23 \cdot 1 \\
14 \cdot 6\end{array}$ \\
\hline
\end{tabular}

$\chi^{2} 4 \cdot 781 ; \mathrm{n}=3 ; 0 \cdot 2>\mathrm{P}>0 \cdot 1$.

4. The last aspect of behaviour to be considered is delinquency. We know of all children who are brought before the courts between the ages of 8 and 17. The proportions are closely similar for those having measles before the age of 6 (4.9\% delinquent) and for those having measles later or not at all $(4.7 \%$ delinquent $){ }^{3}$ so that there is no evidence that early measles is associated with troublesome behaviour in later school life.

\section{Summary}

The National Survey of Health and Development provides information about the history of measles, and the educational progress and emotional stability of 3,729 children who were followed up over a period of 15 years. There is no suggestion from this survey that children who have measles are impaired in their later educational progress. Those who get measles early, before the age of 2, do rather worse in tests of mental ability and school performance than the rest of the children, but this is sufficiently explained by their adverse home circumstances. There is also no evidence from this survey that children who get measles early show an excess of later

- Girls and boys are combined in these figures, and the incidence of delinquency is artificially low because of the sampling procedure used in this inquiry, see The Home and the School (Douglas, 1964), p. 4. abnormalities of behaviour; indeed, those who get measles late are rather more nervous than the rest, perhaps because they have been overprotected in infancy and childhood. These conclusions are by no means incompatible with those of the much larger survey made by Miller (1964) on the frequency of complications in measles in 1963 . He notes that measles yields a formidable toll of complications; however, most patients recover completely, though in an important minority permanent disabilities may result. This is no doubt a correct assessment, but in a survey of only 3,729 children these serious complications are rare and the great majority of children who have measles do not suffer any detectable educational or behavioural handicaps.

The National Survey of Child Health and Development was sponsored by a joint committee of the Institute of Child Health, the Society of Medical Officers of Health, and the Population Investigation Committee. It is now being directed from the Medical Research Council Unit at the London School of Economics. In its early years the inquiry was financed by the Nuffield Foundation, and grants for continuing it through the school years have come from many sources, including the Ford Foundation and the Population Council, Inc.

This study was possible only because of the generous help given by medical officers of health, school medical officers, health visitors, directors of education, school nurses, and teachers in all parts of Great Britain. We should also like to thank the mothers who willingly answered numerous detailed questions, and their children who were on several occasions examined by the school medical officers.

\section{REFERENCES}

Brit. med. 7., 1964, 2, 72.

Douglas, J. W. B. (1964). The Home and the School. MacGibbon and Kee, London.

and Blomfield, J. M. (1958). Children Under Five. Allen and and Blomfield, Miller, D. L. (1964). Brit. med. f., 2, 75.

Mulligan, G., Douglas J. W. B., Hammond, W. A., Tizard, J. (1963). Proc. roy. Soc. Med., 56, 1083.

Report of the Committee on Maladjusted Children, 1955. H.M.S.O., London.

\title{
Value of Premixed Nitrous-oxide-and-oxygen Mixtures in the Relief of Post-operative Pain
}

\section{Double-blind Trial of $25 \%$ Nitrous Oxide in Oxygen, $15 \%$ Nitrous Oxide in Oxygen, and Oxygen}

\author{
GEOFFREY D. PARBROOK,* M.B., CH.B., F.F.A. R.C.s. ; BRYAN R. KENNEDY, $\dagger$ M.B., CH.B., F.F.A. R.c.s.
}

A previous trial (Parbrook et al., 1964) showed that a $25 \%$ nitrous-oxide-in-oxygen mixture had considerable potency for relief of post-operative pain without serious side-effects. To investigate the practicability of its clinical use a double-blind trial was made with varying strengths of the mixture, using apparatus of the type already in routine ward use for oxygen administration.

The trial was limited to patients under the age of 60 who were to have upper abdominal operations and who were willing

\footnotetext{
- Senior Registrar, Department of Anaesthetics, the Royal Infirmary and University of Aberdeen.

t Senior House Officer, Department of Anaesthetics, the Royal Infirmary and University of Aberdeen. At present: Registrar, United Cardift
} Hospitals. to co-operate in the trial. A series of pain-free volunteers acted as controls. Pain relief was assessed by the technique of Overholt (1930), and Bromage (1955), and Masson (1962), who showed that wound pain reduces the vital capacity of patients after operation, and the degree of improvement of the vital capacity with treatment can be used to provide an index of the degree of pain relief.

\section{Apparatus and Method}

Comparative vital capacity readings were obtained using a Wright respirometer with a rubber mouth-piece attached and a nose-clip in situ. Three consecutive readings were taken on 
each occasion and the mean was calculated. Pre-operative readings were taken the day before operation, while postoperative readings were taken during the first 48 hours at a time when no analgesic drug had been administered within the preceding four hours. Immediately after the measurement of the post-operative vital capacity, gas from one of the three cylinders was administered at 8 litres a minute by means of a plastic B.L.B. mask.

The contents of the three cylinders of gases used in the trial were: (1) $25 \%$ nitrous oxide in oxygen (premixed under pressure), (2) $15 \%$ nitrous oxide in oxygen (premixed under pressure), and (3) oxygen only.

Each gas was inhaled for 15 minutes, after which fresh vital , capacity recordings were taken. The cylinders were enclosed in linen bags and given code letters by an assistant and were used in various orders so that in each group of six patients each patient received a different order of cylinders.

\section{Results}

The changes in the vital capacity recordings in 12 patients and in 12 volunteers are shown respectively in Tables I and II.

The changes in vital capacity were examined by the standard analysis of variance technique (Table III) to separate out the different sources of variation. The residual mean square is an estimate of the variance of repeated measurements for the same patients, and can thus be used to test the significance of the factors of interest. The effect of order of recording is not significant, but the probability of obtaining an $F$ ratio as large as $\mathbf{2 4 . 1 1}$ for treatments by chance is negligible ( $P$ is much less

TABLE I.-Patients' Vital Capacity Recordings (Mean of Three Readings)

\begin{tabular}{|c|c|c|c|c|c|c|}
\hline \multirow{2}{*}{$\begin{array}{l}\text { Patient } \\
\text { No. }\end{array}$} & \multirow{2}{*}{$\begin{array}{l}\text { Pre-Op. } \\
\text { v.c. }\end{array}$} & \multirow{2}{*}{$\begin{array}{l}\text { Post-Op. } \\
\text { V.C. }\end{array}$} & \multicolumn{3}{|c|}{$\begin{array}{l}\text { Change of Recording (in ml.) } \\
\text { after Inhalation of : }\end{array}$} & \multirow{2}{*}{ Order } \\
\hline & & & $\begin{array}{c}\text { (A) } \\
\text { Oxygen }\end{array}$ & $15 \%{ }^{(\mathrm{B})} \mathrm{N}_{2} \mathrm{O}$ & $\underset{25 \% \mathrm{~N}_{2} \mathrm{O}}{(\mathrm{C})}$ & \\
\hline $\begin{array}{r}1 \\
2 \\
3 \\
4 \\
5 \\
6 \\
7 \\
8 \\
9 \\
10 \\
11 \\
12\end{array}$ & $\begin{array}{l}2,200 \\
2,730 \\
1,230 \\
4,050 \\
4,300 \\
4,460 \\
4,420 \\
3,420 \\
3,480 \\
4,810 \\
3,440 \\
2,570\end{array}$ & $\begin{array}{r}1,690 \\
810 \\
960 \\
1,220 \\
1,870 \\
2,210 \\
3,150 \\
2,130 \\
1,050 \\
1,010 \\
1,070 \\
1,180\end{array}$ & $\begin{array}{r}+330 \\
+10 \\
+170 \\
-70 \\
-90 \\
-20 \\
+10 \\
-110 \\
+80 \\
-50 \\
+230 \\
-90\end{array}$ & $\begin{array}{r}+580 \\
+80 \\
+30 \\
0 \\
+100 \\
+70 \\
+210 \\
+230 \\
+120 \\
+460 \\
+80\end{array}$ & $\begin{array}{r}+680 \\
+240 \\
+160 \\
+220 \\
+90 \\
+150 \\
+660 \\
+200 \\
+230 \\
+260 \\
+430 \\
+250\end{array}$ & $\begin{array}{l}\mathrm{ABC} \\
\mathrm{BAC} \\
\mathrm{BCA} \\
\mathrm{CAB} \\
\mathrm{CBA} \\
\mathrm{ACB} \\
\mathrm{BAC} \\
\mathrm{ACB} \\
\mathrm{BCA} \\
\mathrm{ABC} \\
\mathrm{CAB} \\
\mathrm{CBA}\end{array}$ \\
\hline \multicolumn{3}{|c|}{ dings } & +33 & +150 & +298 & \\
\hline
\end{tabular}

TABLB II.-Volunteers' Vital Capacity Recordings (Mean of Three

\begin{tabular}{|c|c|c|c|c|c|}
\hline \multicolumn{6}{|c|}{ Recordings) } \\
\hline \multirow{2}{*}{$\begin{array}{l}\text { Volunteer } \\
\text { No. }\end{array}$} & \multirow{2}{*}{$\begin{array}{l}\text { Preliminary } \\
\text { V.C. }\end{array}$} & \multicolumn{3}{|c|}{$\begin{array}{l}\text { Change of Recording (in ml.) } \\
\text { after Inhalation of : }\end{array}$} & \multirow{2}{*}{ Order } \\
\hline & & $\begin{array}{c}\text { (A) } \\
\text { Oxygen }\end{array}$ & $15 \% \mathrm{~N}_{2} \mathrm{O}$ & $25 \% \mathrm{~N}_{2} \mathrm{O}$ & \\
\hline $\begin{array}{r}1 \\
2 \\
3 \\
4 \\
5 \\
6 \\
7 \\
8 \\
9 \\
10 \\
11 \\
12\end{array}$ & $\begin{array}{l}5,130 \\
5,070 \\
5,450 \\
5,440 \\
4,810 \\
6,510 \\
4,240 \\
4,310 \\
5,740 \\
3,700 \\
6,120 \\
3,430\end{array}$ & $\begin{array}{r}-130 \\
+70 \\
+70 \\
-140 \\
-190 \\
-50 \\
-40 \\
-100 \\
+60 \\
+100 \\
+120 \\
-130\end{array}$ & $\begin{array}{r}-90 \\
+110 \\
+130 \\
+90 \\
+20 \\
-80 \\
-130 \\
-150 \\
+110 \\
-120 \\
+360 \\
-40\end{array}$ & $\begin{array}{r}-120 \\
+40 \\
+50 \\
+20 \\
-200 \\
+60 \\
+60 \\
+240 \\
+300 \\
+70 \\
+250 \\
+210\end{array}$ & $\begin{array}{l}\mathrm{ACB} \\
\mathrm{BAC} \\
\mathrm{CBA} \\
\mathrm{CAB} \\
\mathrm{ABC} \\
\mathrm{BCA} \\
\mathrm{BAC} \\
\mathrm{CBA} \\
\mathrm{ABC} \\
\mathrm{BCA} \\
\mathrm{ACB} \\
\mathrm{CAB}\end{array}$ \\
\hline \multicolumn{2}{|c|}{ Mean of readings } & -42 & +18 & -5 & \\
\hline
\end{tabular}

TABLE III.-Analysis of Variance (Patients)

\begin{tabular}{|c|c|c|c|c|c|}
\hline \multicolumn{2}{|l|}{ Source of Variation } & $\begin{array}{c}\text { Degrees of } \\
\text { Freedom }\end{array}$ & $\begin{array}{l}\text { Sum of } \\
\text { Squares }\end{array}$ & $\begin{array}{l}\text { Mean } \\
\text { Square }\end{array}$ & F Ratio \\
\hline $\begin{array}{l}\text { Patients } \\
\text { Order of recording } \\
\text { Treatments } \quad: . \\
\text { Residual } \\
\end{array}$ & $\begin{array}{l}. \\
\ddot{.} \\
.\end{array}$ & $\begin{array}{r}11 \\
2 \\
2 \\
20\end{array}$ & $\begin{array}{l}836,164 \\
33,472 \\
420,605 \\
174,456\end{array}$ & $\begin{array}{r}76,015 \\
16,736 \\
210,302 \\
8,723 \\
\end{array}$ & 24.11 * \\
\hline Total & $\overline{. .}$ & 35 & $1,464,697$ & & \\
\hline
\end{tabular}

- Significant at the $0.1 \%$ level. than 0.001). The improvements in vital capacity with individual treatments can be examined by the use of the standard error of mean differences derived from the residual variance (Table IV). The $t$ values for increases in means between oxygen and $15 \%$ nitrous oxide $(t=3.06 ; \mathrm{P}<0.01)$ and between $15 \%$ and $25 \%$ nitrous oxide $(\mathrm{t}=3.87 ; \mathrm{P}<0.001)$ are both highly significant.

The similar experiment on volunteers was analysed by the same procedures (Table $\mathrm{V}$ ). The residual mean square is consistent with that of the previous experiment, but, in accord with expectation, the variability among subjects rather less. The order effect is significant, clearly because of progressive improvements in the volunteers' performance as shown by the successive mean changes in vital capacity in $\mathrm{ml}$. $(-61.7,-0.8$, +33.3 ). There is no indication of any significant influence of treatments on the results.

TABLE IV

\begin{tabular}{|c|c|c|c|}
\hline \multicolumn{3}{|c|}{ Mean Change in Vital Capacity (ml.) } & \multirow{2}{*}{$\begin{array}{l}\text { Standard Error } \\
\text { of Mean } \\
\text { Difference }\end{array}$} \\
\hline Oxygen & $15 \%$ Nitrous Oxide & $25 \%$ Nitrous Oxide & \\
\hline $33 \cdot 3$ & $150 \cdot 0$ & $297 \cdot 5$ & $38 \cdot 1$ \\
\hline
\end{tabular}

TABLE V.-Analysis of Variance (Volunteers)

\begin{tabular}{|c|c|c|c|c|c|}
\hline \multicolumn{2}{|c|}{ Source of Variation } & $\begin{array}{c}\text { Degrees of } \\
\text { Freedom }\end{array}$ & $\begin{array}{l}\text { Sum of } \\
\text { Squares }\end{array}$ & $\begin{array}{l}\text { Mean } \\
\text { Square }\end{array}$ & F Ratio \\
\hline $\begin{array}{l}\text { Volunteers } \\
\text { Qrder of recording } \\
\text { Treatments } \quad \ldots \\
\text { Residual }\end{array}$ & $\begin{array}{l}\ldots \\
\cdots \\
\cdots\end{array}$ & $\begin{array}{r}11 \\
2 \\
2 \\
20\end{array}$ & $\begin{array}{r}489,030 \\
55,572 \\
21,404 \\
146,291 \\
\end{array}$ & $\begin{array}{r}44,457 \\
27,786 \\
10,702 \\
7,315 \\
\end{array}$ & $\begin{array}{l}3 \cdot 80^{*} \\
1 \cdot 46\end{array}$ \\
\hline Total & .. & 35 & 712,297 & & \\
\hline
\end{tabular}

* Significant at the $5 \%$ level.

The above vital capacity readings were based on the mean of three consecutive recordings. Although these recordings would occupy about a minute, the rapid fall of alveolar nitrous oxide level in these circumstances led us to examine the individual readings to see if any rapid loss of the effects of nitrous oxide could be detected (Table VI). The results demonstrate

TABLE VI.-Separated Vital Capacity Readings in Patients

\begin{tabular}{l|c|c|c}
\hline & \multicolumn{3}{|c}{ Change of Readings (in ml.) (Mean of 12 Patients) } \\
\cline { 2 - 4 } & 1st Reading & 2nd Reading & 3rd Reading \\
\hline $\begin{array}{l}\text { After } 15 \% \text { nitrous oxide } \\
\text { After } 25 \% \text { nitrous oxide }\end{array}$ & $\begin{array}{l}+134 \\
+238\end{array}$ & $\begin{array}{l}+168 \\
+323\end{array}$ & $\begin{array}{l}+145 \\
+334\end{array}$ \\
\hline
\end{tabular}

that rapid loss of the effects of nitrous oxide does not occur during the taking of the readings. This agrees with previous results (Parbrook et al., 1964), in which analgesia was lost only gradually over 15 minutes. Although alveolar nitrous oxide levels fall rapidly, fall of tension in the brain will be slower, and there is evidence that, after administration of the gas has ceased, analgesia and other effects of nitrous oxide may last longer than expected (Jarvik and Adler, 1961 ; Eastwood et al., 1963).

\section{Side-effects}

In common with the previous trial, in which $25 \%$ nitrous oxide was used (Parbrook et al., 1964), no untoward side-effects or symptoms were noted in the patients. After completion of the trial it was found that eight of the volunteers had been able to identify the contents of the cylinders subjectively, and three volunteers regarded the $25 \%$ nitrous oxide mixture as mildly unpleasant. Four volunteers, however, regarded this mixture as mildly pleasant, while five were unable to identify the mixture or had no special comment to make on this aspect.

The incidence of side-effects depends on the concentration of nitrous oxide used, and in this trial, owing to two main factors, the effective concentration was only about threequarters of the cylinder concentration of nitrous oxide. Firstly, the plastic B.L.B. masks allow about $15 \%$ air dilution in the 
conditions of this trial (J. Ernsting, personal communication, 1964), and, secondly, the alveolar level of nitrous oxide shows an initial rise to about $90 \%$ of the inspired concentration, after which a very slow further rise of concentration occurs. This is due to a "concentration" effect described by Eger (1963a, 1963b) in which the lower the inspired concentration of a gas the slower the rise in alveolar concentration to that inspired. On the other hand, the 15 minutes permitted in this trial is probably adequate for initial equilibration of arterial to alveolar tension of nitrous oxide (Kety and Schmidt, 1945, 1948), although an uneven ventilation-perfusion relationship may be present in the patients (Nunn and Payne, 1962 ; Palmer and Gardiner, 1964).

The side-effects to be expected with slightly higher concentrations of nitrous oxide have been investigated in volunteers by several workers (Seevers et al., 1937 ; Sonnenschein et al., 1948 ; Steinberg, 1953, 1956; Delisle Burns et al., 1960 ; Parkhouse et al., 1960 ; Robson et al., 1960). As the concentration of nitrous oxide is raised from $30 \%$ to $40 \%$ there is a progressive impairment of memory and of time sense and rise of sensory thresholds. These effects should not cause undue difficulties with its clinical use. Two more serious sideeffects are:

1. Unconsciousness.-Most investigators have found that occasional volunteers lose contact with their environment when nitrous-oxide concentrations of $35 \%$ or $40 \%$ have been inhaled for over 10 minutes. Steinberg (1956), however, found that an occasional volunteer lost consciousness when breathing $30 \%$ nitrous oxide.

2. Psychological Disturbances and Unpleasant Neurological Effects.-Although many volunteers experience euphoria a substantial minority find low-percentage nitrous oxide unpleasant. Tingling, numbness, dizziness, and auditory disturbances are common when $30 \%$ nitrous oxide is inhaled by volunteers, and more serious side-effects such as nausea, delusions, visual phenomena, and aggressive tendencies may appear as the concentration is increased to $40 \%$ or $50 \%$. It will be appreciated, however, that the psychological effects of nitrous oxide in the patient suffering pain may be different from those in pain-free volunteers. Furthermore, patients who experience euphoria with these mixtures may be running a risk of addiction. It is because of the risk of unconsciousness and psychological effects that we have restricted our present clinical investigations to $25 \%$ nitrous oxide.

\section{Discussion}

The problems of post-operative analgesia and its measurement have been reviewed by several workers (Simpson and Parkhouse, 1961 ; Swerdlow and Murray, 1962 ; Parkhouse and Holmes, 1963 ; Swerdlow et al., 1963). A marked placebo reaction and patient-variability render it difficult to assess minor degrees of analgesia by subjective response, and it is necessary that the number of patients be large. The technique of Bromage (1955) appears to solve this problem, and it allows minor degrees of analgesia to be assessed in a relatively small group of patients provided the treatment given does not affect vital capacity in the pain-free subject.

The role of pain from abdominal wounds in the production of chest complications has been emphasized by Parkhouse and Simpson (1964) following a leading article on the post-operative chest in the Lancet (1964). To strike a balance with opiates alone between adequate analgesia and a combination of respiratory depression and cough suppression is always difficult and often impossible. An alternative has been put forward by Simpson et al. (1961) in the form of thoracic extradural analgesia, but the technical expertise and constant supervision demanded for its success preclude its general use. Nitrousoxide-and-oxygen analgesia commends itself by the absence of respiratory depression and speed of action, while the use of premixed gases (Tunstall, 1961) avoids cumbersome apparatus and the danger of variation in concentration of the gases. Premixed nitrous-oxide-and-oxygen mixtures are already in use in maternity hospitals for the relief of labour pains, and the extension of their use to the treatment of other forms of pain seems likely. Recent increased emphasis on the presence of hypoxia after surgical operations (Nunn and Payne, 1962 ; Conway and Payne, 1964 ; Palmer and Gardiner, 1964) has encouraged the freer use of oxygen in the post-operative period, and there is no technical difficulty in replacing the cylinder of oxygen with one of premixed nitrous oxide and oxygen.

The side-effects of nitrous oxide have already been discussed, but there is also the problem of toxicity to the bone-marrow when higher concentrations of nitrous oxide have been inhaled for several days, and this aspect has been reviewed comprehensively by Green (1964).

\section{Summary}

Vital capacity measurements were used to assess relief of post-operative pain after inhaling special premixed nitrousoxide-and-oxygen mixtures containing $25 \%$ nitrous oxide in oxygen and $15 \%$ nitrous oxide in oxygen. Oxygen only was used as a control. A series of 12 patients revealed an improvement of vital capacity after $15 \%$ nitrous oxide and an even greater improvement after $25 \%$ nitrous oxide, whereas a similar series of 12 pain-free volunteers showed no such effect. It is concluded that inhalation of a $25 \%$ nitrous-oxide mixture for brief periods can be of value in the early post-operative period. Possible side-effects and other aspects of this form of treatment are considered.

We wish to thank Messrs. David Blair, Charles Clark, Peter Jones, and James Kyle, Consulting Surgeons, Aberdeen Teaching Hospitals, for permission to conduct this research on patients under their care, and the British Oxygen Company for loaning us the equipment and cylinders used in this trial. Our thanks are also due to Dr. W. Brass, Senior Lecturer, Department of Statistics, for his advice; to Dr. W. N. Rollason, Director, Department of Anaesthetics, for his encouragement and help, and to those members of the department who acted as volunteers.

\section{REFERENCES}

Bromage, P. R. (1955). Brit. med. f., 2, 589.

Conway, C. M., and Payne, J. P. (1964). Lancet, 1, 12.

Delisle Burns, B., Robson, J. G., and Welt, P.' J. L. (1960). Can. Anaesth. Soc. F., 7, 411 .

Eastwood, D. W., Green, C. D., Lambdin, M. A., and Gardner, R. (1963). New Engl. f. Med., 268, 297.

Eger, E. I. (1963a). In Uptake and Distribution of Anaesthetic Agents, edited by E. M. Papper and R. J. Kitz. McGraw-Hill, New York. - (1963b). Anesthesiology, 24, 153.

Green, C. D. (1964). Clinical Anaesthesia, p. 38. Blackwell, Oxford.

Jarvik, M. E., and Adler, M. W. (1961). f. Pharmacol. exp. Ther., 131, 108.

Kety, S. S., and Schmidt, C. F. (1945). Amer. F. Physiol., 143, 53.

Lancet, 1964 1, 153 . clin. Invest., 27, 476

Lancet, 1964, 1, 153.

Masson, A. H. (1962). Anesth. Analg. Curr. Res., 41, 615.

Nunn, J. F., and Payne, J. P. (1962). Lancet, 2, 631

Overholt, R. H. (1930). ₹. Amer. med. Ass., 95, 1484.

Palmer, K. N. V., and Gardiner, A. J. S. (1964).' Brit. med. f., 1, 347 arbrook, G. D., Rees, G. A. D., and Robertson, G. S. (1964). Ibid., 2, 480 .

Parkhouse, J., Henrie, J. R., Duncan, G. M., and Rome, H. P. (1960). f. Pharmacol. exp. Ther., 128, 44.

- and Holmes, C. M. (1963). Proc. roy. Soc. Med., 56, 579.

- and Simpson, B. R. (1964). Lancet, 1, 272.

Robson, J. G., Delisle Burns, B., and Welt, P. J. L. (1960). Can. Anaesth. Soc. F., 7, 399.

Seevers, M. H., Bennett, J. H., Pohle, H. W., and Reinardy, E. W. (1937). 7. Pharmacol. exp. Ther., 59, 291.

Simpson, B. R. J., and Parkhouse, J. (1961). Brit. 7. Anaesth., 33, 336. Son Marshall, R., and Lambrechts, W. (1961). Ibid., 33, 628. Sonnenschein, R. R., Jamison, R., Loveseth, L. J., Cassels, W. H., and

Steinberg, H. (1953). Ph.D. thesis, London.

(1956). Brit. F. Psychol., 47, 183.

Swerdlow, M., and Murray, A. (1962). Proceedings First European Congress of Anaesthesiology (Vienna), 1, 21.

Tunstall, M. E. (1961). Lancet, 2, 964. 